\title{
INCIDENCES OF THE PUBLIC AGENDA ON CITIZENS' POLITICAL ATTITUDES THROUGH THE THEORY OF FORGOTTEN EFFECTS
}

\author{
Mauricio Ortigosa Hernández \\ School of Business and Economics \\ Anáhuac University Mexico \\ Huixquilucan, State of Mexico, Mexico \\ mauricio.ortigosa@anahuac.mx
}

\begin{abstract}
Reception date: 01/30/2020 - Revision date: 04/20/2020 - Approval Date: 06/11/2020
DOI: https://doi.org/10.36995/j.visiondefuturo.2021.25.01.001.en
\end{abstract}

\begin{abstract}
This study contributes to the field of political marketing through the use of instruments based on the Theory of Forgotten Effects. According to this theory, when individuals attribute value to the incidences or connections between two sets of entities, with one set acting as the cause and the other as effect, intervening elements sometimes remain hidden, thus resulting in forgotten effects.
\end{abstract}

To demonstrate the above, a group of citizens from the western Mexico City Metropolitan Area including the townships of Huixquilucan de Degollado and Naucalpan de Juárez in the State of Mexico were asked to determine the incidences between two sets of entities: on the one hand, issues from Mexico's public agenda, and, on the other, the political attitudes of citizens. The interviews were collected shortly before the 2018 campaign for the presidency and other popularly elected offices began.

The results show that the citizens did not identify several elements that are interpolated as forgotten effects between the two entities mentioned above, such as corruption, the economy, and trust in government leaders, among others.

KEY WORDS: Forgotten effects; Uncertainty; Political marketing; Political attitudes; Public agenda.

\section{INTRODUCTION}

The advance of Mexico's young democracy has been gradual. Reforms made to the electoral system since the 1970s have allowed the subject of elections to occupy spaces of interest for public opinion (B.M.S. García, 2011). Nonetheless, as this same author observes, despite numerous electoral reforms at the federal level, in their desire for power, politicians in Mexico have become mired in the vices of the political system and stopped serving the cause that put them in office.

In his book, García Montaño (2004) establishes that political and electoral democracy is the most refined format that postmodern societies must agree to on matters of public power

\footnotetext{
"Visión de Futuro" Año 18, Volumen No 25 N 1, Enero - Junio 2021 - Pág 24 - 42

URL de la Revista: http://visiondefuturo.fce.unam.edu.ar/index.php/visiondefuturo/index

URL del Documento: https://visiondefuturo.fce.unam.edu.ar/index.php/visiondefuturo/issue/view/19

ISSN 1668 - 8708 - Versión en Línea

E-mail: revistacientifica@fce.unam.edu.ar
} 
and government. However, as Morris (2011) points out, Mexico faces a serious problem of lack of the rule of law and respect for the law by society (for example, the informal market) and the state itself (for example, corruption and violation of human rights), which has led Mexicans to have little trust in the law, government institutions, and politicians. Duarte and Jaramillo (2009), note that the authoritarian regime that characterized the political culture of Mexicans in the last century has caused citizens to develop a sense of apathy and lack of interest in political phenomena.

Tronco (2012) comments that there is a fundamental assumption that political trust is essential for democracy. This trust links citizens to the institutions designed to represent their interests. Unfortunately, as the same author notes, the National Survey on Political Culture and Citizen Practices (ENCUP) conducted by the Secretariat of the Interior in 2008 shows that the lack of trust among Mexican citizens is explained primarily by the deficient performance that citizens attribute to their representatives.

Rodríguez-Virgili, López-Escobar, and Tolsá (2011) rightly point out that the loss of prestige in Mexican politics over the last few years should not be considered a minor issue, and that we should regard this development with caution for three reasons: in the first place, many citizens affirm that they do not have the slightest interest in politics; secondly, we must take into account that politics do not have the same meaning for everyone; and finally, the rejection of politicians is not necessarily equivalent to a lack of interest in politics. On the contrary, criticism can be a reflection of interest.

The impact of these attitudes of trust and interest, among others, towards political phenomena, whether positive or negative, are studied in this paper, through an unconventional technique that seeks to establish causal relations as in a regression analysis or its specific technique for structural equations. The tool we propose to implement is situated within the framework of the Theory of Forgotten Effects to study both direct and indirect causal relations.

To illustrate this tool, we use topics from a public agenda prepared by Corral (2016) for a 2011-2012 pre-electoral study in Mexico. The topics on this public agenda are considered the causes of the model, while the political attitudes of citizens will be considered as the effects. By applying the Theory of Forgotten Effects, we identify those relations of incidence or causality concealed within the public agenda and political attitudes.

\section{DEVELOPMENT}

\section{The Public Agenda}

In the field of political science, the meaning of the term agenda, as defined by Maldonado and Casar (2008), is simply a set of topics or issues that are to be advanced or that are

\footnotetext{
"Visión de Futuro" Año 18, Volumen No 25 N 1, Enero - Junio 2021 - Pág 24 - 42

URL de la Revista: http://visiondefuturo.fce.unam.edu.ar/index.php/visiondefuturo/index

URL del Documento: https://visiondefuturo.fce.unam.edu.ar/index.php/visiondefuturo/issue/view/19

ISSN 1668 - 8708 - Versión en Línea

E-mail: revistacientifica@fce.unam.edu.ar
} 
important to take into account in order to understand the reality experienced by individuals or a society.

Different agendas are considered in the literature as a function of the social actors involved. We can identify the public agenda, the political agenda, the government agenda, and even the agenda of the media. Several authors (Aruguete, 2009; Bouza, 2012; M.J. García, 2011; Corral, 2016; Maldonado and Casar, 2008; Petrone, 2009; Rubio, 2009; Stubager, 2015), have studied these agendas within a political framework.

Of the different agendas mentioned, in this study, we focus on the public agenda, using two aspects as a frame of reference: what are these agendas, and how are they developed? With respect to the first item, the public agenda is defined as a list of topics that citizens and different groups in society seek to position for consideration by the representatives (Macassi, 1999; Maldonado and Casar, 2008; Petrone, 2009). In terms of the second aspect, Tamayo and Carrillo (2005) note that one way to set the public agenda is to use opinion polls on the problems or issues that people consider important for their representatives to resolve. In this regard, Petrone (2009) affirms that the highest proportion or percentages obtained from said surveys should become the top priorities on the public agenda.

When setting the public agenda, the list is determined by the number of issues mentioned by citizens when asked, What do you think is the most important problem facing the country today? McCombs and Evatt (1995) note that this list is very limited by nature and rarely exceeds five or seven topics. This limitation is possibly an important factor in the media's power to include more topics on the agenda.

The issues from the public agenda used in this research were taken from a study conducted by Corral (2016) about pre-electoral issues in Mexico in the 2011-2012 period.

Having presented our understanding of the concept of agenda, which is the entity used to identify the causes in the Forgotten Effects methodology, we are going to present the second entity considered as the effects, which are the political attitudes that citizens adopt.

\section{Political Attitudes (an approximation)}

In order to establish the meaning of citizens' political attitudes, it is important to clarify the meaning of certain terms. Mateos (2004) defines an attitude as a set of beliefs focused on a particular object or situation that provides a favorable or unfavorable response facilitating an individual's predisposition. In particular, if that object is the political system or politics of a given country or nation, we can then speak of political attitudes.

However, in order to obtain a fuller understanding of political attitudes, we must situate them within the definition of political culture.

\footnotetext{
"Visión de Futuro" Año 18, Volumen No 25 No 1, Enero - Junio 2021 - Pág 24 - 42

URL de la Revista: http://visiondefuturo.fce.unam.edu.ar/index.php/visiondefuturo/index

URL del Documento: https://visiondefuturo.fce.unam.edu.ar/index.php/visiondefuturo/issue/view/19

ISSN 1668 - 8708 - Versión en Línea

E-mail: revistacientifica@fce.unam.edu.ar
} 
The study of political culture is not new and dates back to the middle of the last century. In the 1960s, Almond and Verba established a first definition arguing that "the political culture of a nation is the particular distribution of patterns of orientation toward political objects among the members of the nation" (Mateos, 2004, p. 94).

In this paper, we adopt the following definition of political culture: "the values, conceptions, and attitudes that are directed towards the specifically political sphere, that is, the set of elements that configure the subjective perception that a population has with respect to power" (Peschard, 2019, p. 20), confirming that attitudes are only one component of the political culture.

Following the classic definition established by Almond and Verba, Mateos (2004) states that the operationalization of the concept of political culture allows it to be divided into three types of political dimensions or orientations: the cognitive dimension, which refers to the information and knowledge one has about the political system as a whole, and about its roles and actors in particular; the affective dimension, which refers to the feelings one has regarding the political system, which may be of adherence or rejection, and lastly, the evaluative dimension, which refers to the population's judgments and opinions about the political system. Each of these dimensions is, in turn, comprised of political attitudes, beliefs, and values.

From these three dimensions, we focus on the attitudes that are specific to each of them. However, we must clarify that the judgments and opinions of the third evaluative dimension include the valuation of individuals as subjects participating in political life. Therefore, some Spanish scholars such as Óscar García Luengo refer to this component as the behavioral dimension to designate political attitudes that demonstrate levels of activism or civic and political participation (Aruguete and Muñiz, 2012). Consequently, this paper adopts the term behavioral for the third dimension. It is worth mentioning that participation can take place at different levels, ranging from exercising the right that every citizen has to vote, to implementing or having specific responsibilities within a political party. We will take this participatory attitude within the behavioral dimension into account in our model.

Within the affective dimension, an attitude incorporated in this study is the trust that links citizens with the institutions created to represent their interests (Tronco, 2012). This attitude of trust is another one that we must take into account in our study for government leaders, political parties, and institutions.

Lastly, in this article, we incorporate the attitude of interest in political issues under the cognitive dimension. Political scientist Pippa Norris affirms that people exposed to the media and electoral campaigns are more knowledgeable in terms of politics; they trust the government and the political system and are more involved in electoral processes (García,

\footnotetext{
"Visión de Futuro" Año 18, Volumen No 25 No 1, Enero - Junio 2021 - Pág 24 - 42

URL de la Revista: http://visiondefuturo.fce.unam.edu.ar/index.php/visiondefuturo/index

URL del Documento: https://visiondefuturo.fce.unam.edu.ar/index.php/visiondefuturo/issue/view/19

ISSN 1668 - 8708 - Versión en Línea

E-mail: revistacientifica@fce.unam.edu.ar
} 
2005). Norris (2001) has called this position a virtuous circle, where, in the long term, the media serve to make those most interested more aware of these issues.

Norris cites Kurt and Gladys Lang (1966) to mention that before the so-called virtuous circle, these authors were the first to suggest the opposite position, arguing that excessive exposure of citizens to political information channels produces a negative effect, generating a sense of disconnection from politics (Norris, 2001). Robinson (1976) was the first to popularize the term videomalaise to describe the negative effect generated by the media with their audiences in terms of political topics.

We can say that citizens' political attitudes are influenced not only by the media, but are also shaped through the different elements involved in the lives of individuals, such as environmental factors, coworkers, and family, among others.

Having described the meaning that we attribute to the public agenda and the term political attitudes, we now present a brief reflection on the existing literature, applying the methodology we selected in this article to different areas.

\section{Application of the Methodology to Other Areas}

The methodology used in this study is located within the framework of the Theory of Forgotten Effects. Carreón, Figueroa, and Montoya (2017) comment that we are nothing more than human beings; intelligent, but not always reliable. In fact, even with the most powerful computers to manage information, the risk of forgetfulness will never disappear.

The literature on this methodology applied to political issues is practically non-existent. However, it has been widely used in the study of social, economic, financial, and accounting phenomena, among others.

As an example of the above, we can mention the paper written by Gil Lafuente and Barcellos (2010), whose objective is to promote the sustainable growth of companies through two entities. The first is comprised of factors related to a country's political environment, such as its political stability, level of corruption, and armed conflicts, among others. The second entity is comprised of elements within a company, such as its internal politics, professional ethics, talent development, and financial-economic viability, among others.

Another study is that published by Salazar-Garza (2012), where he links certain macroeconomic and microeconomic variables of the Mexican currency market that influence the determination of the peso-dollar equilibrium exchange rate.

For his part, Álvarez (2016) presents the incidence of certain variables proposed by a group of experts on the exchange risk faced by small and medium-sized manufacturing companies.

\footnotetext{
"Visión de Futuro" Año 18, Volumen No 25 No 1, Enero - Junio 2021 - Pág 24 - 42

URL de la Revista: http://visiondefuturo.fce.unam.edu.ar/index.php/visiondefuturo/index

URL del Documento: https://visiondefuturo.fce.unam.edu.ar/index.php/visiondefuturo/issue/view/19

ISSN 1668 - 8708 - Versión en Línea

E-mail: revistacientifica@fce.unam.edu.ar
} 
In the field of marketing, Tinto, Luna, and Cisneros (2017) used this methodology to identify Forgotten Effects in rescuing the commercial image of a group of artisans in a province of Ecuador.

Despite all these applications and many more found in the literature, we were only able to identify one paper (Sarasola, 2004) that used this methodology for political marketing. That paper starts with the hypothesis that political campaigns preceding elections must secure electoral victory for candidates. The causes were the different means of information and the effects of the perceptions about the candidates based on their personal attributes. The study found Forgotten Effects not readily perceived by those interviewed.

When analyzing certain characteristic features of the problems solved with the Theory of Forgotten Effects models, we can note that one of the advantages of using this methodology is the possibility of studying causal relations in complex phenomena, where in many cases the behavior is not aligned with variables or determinants that have a degree of imprecision according to a systemic character, where there are mutual interrelationships that condition and influence each other to produce effects.

Given that there is practically no literature applying the Theory of Forgotten Effects to political marketing, we apply these unconventional tools to this field of study, rather than traditional statistical methods. This methodology is described below, followed by an empirical application.

\section{Methodology}

The concept of incidence is used or associated with the idea of an effect caused by one set of entities (causes) on another set of entities (effects) or on itself. In this manner, we can say, for example, that the creation of jobs impacts trust in politicians, which simultaneously impacts interest in politics.

Kaufmann and Gil Aluja (1988) note that the concept of incidence is present in all actions of living beings. Even though the notion of incidence is quite simple in itself, the authors mention that incidences, when propagated in a chained manner across a network, often involuntarily omit stages and overlook conclusions. Each omission produces secondary effects that have repercussions across the network of incidence relationships in a kind of combinatorial process, as mentioned by Gil Lafuente and Barcellos (2010). These omissions can often lead to unfavorable secondary consequences regarding the decisions made.

To illustrate how the Theory of Forgotten Effects operates, we will assume that we have a set of entities (causes), which in the empirical study consists of a list of topics on the public agenda about another set of entities (effects), which is also a list of the political attitudes that

\footnotetext{
"Visión de Futuro" Año 18, Volumen $N^{0} 25$ N 1, Enero - Junio 2021 - Pág 24 - 42

URL de la Revista: http://visiondefuturo.fce.unam.edu.ar/index.php/visiondefuturo/index

URL del Documento: https://visiondefuturo.fce.unam.edu.ar/index.php/visiondefuturo/issue/view/19

ISSN 1668 - 8708 - Versión en Línea

E-mail: revistacientifica@fce.unam.edu.ar
} 
citizens experience. We represent these sets with the letters $\mathrm{P}$ (public agenda) and S (political attitudes), respectively:

$$
\begin{aligned}
& P=\left\{p_{i} / i=1,2,3, \ldots n\right\} \text { (causes) } \\
& S=\left\{s_{j} / j=1,2,3, \ldots m\right\} \text { (effects) }
\end{aligned}
$$

We say that there is an incidence of $p_{i}$ in $s_{j}$ if the characteristic function of belonging of the pair $\left(p_{i}, s_{j}\right)$ is valued at $[0,1]$. It is important to recall that the concept of valuation is linked to a subjective measurement, as mentioned by Gil Aluja (2002).

The degree of incidence of each pair $\left(\mathrm{p}_{\mathrm{i}}, \mathrm{s}_{\mathrm{j}}\right)$ can be expressed through a function:

$\mu:$ PXS $\rightarrow[0,1]$ such that $\forall\left(p_{i}, s_{j}\right) \in P X S, \mu\left(p_{i}, s_{j}\right) \in[0,1]$

The matrix formed by the set of elements valued from each element of $P$ to each element

\begin{tabular}{|c|c|c|c|c|c|c|}
\hline \multirow{5}{*}[D]{$=$} & $\nearrow$ & $\mathrm{s}_{1}$ & $\mathrm{~s}_{2}$ & $s_{3}$ & $\ldots$ & $\mathrm{S}_{\mathrm{m}}$ \\
\hline & $p_{1}$ & $\mu\left(p_{1}, s_{1}\right)$ & $\mu\left(p_{1}, s_{2}\right)$ & $\mu\left(p_{1}, s_{3}\right)$ & & $\mu\left(p_{1}, s_{m}\right)$ \\
\hline & $\mathrm{p}_{2}$ & $\mu\left(p_{2}, s_{1}\right)$ & $\mu\left(p_{2}, s_{2}\right)$ & $\mu\left(p_{2}, s_{3}\right)$ & & $\mu\left(p_{2}, s_{m}\right)$ \\
\hline & & & & & $\mu\left(p_{i}, s_{j}\right)$ & \\
\hline & $p_{n}$ & $\mu\left(p_{n}, s_{1}\right)$ & $\mu\left(p_{n}, s_{2}\right)$ & $\mu\left(p_{n}, s_{3}\right)$ & & $\mu\left(p_{n}, s_{m}\right)$ \\
\hline
\end{tabular}
of $S$ is known as the direct incidence or first-generation matrix. Figure $N^{\circ} 1$.

Figure $\mathrm{N}^{\circ} 1$ Direct or first-generation incidence matrix

Source: Prepared by the author

Matrix $[D]$, when each entry $\mu\left(p_{i}, s_{j}\right)$ in the interval $[0,1]$ is valued, will approach value 1 to the extent that there is a higher incidence, while it will approach value 0 to the extent that a lower incidence is valued.

If the matrix [D] reflects the direct, that is, first-generation, relations of cause and effect, we must obtain two new incidence matrices for the purpose of our proposed analysis. On the one hand, the matrix that reflects those incidence relationships within the set of causes among themselves, and on the other hand, an incidence matrix within the set of effects themselves. These matrices are square by nature.

If $[\mathrm{A}]=\mathrm{PXP}$, the incidence matrix of the causes among themselves.

$[A]=\left\{\mu\left(p_{i}, p_{j}\right) \in[0,1] / i, j=1,2,3, \ldots n\right\}$

If $[B]=S X S$, the incidence matrix of the effects among themselves.

$[B]=\left\{\mu\left(s_{i}, s_{j}\right) \in[0,1] / i, j=1,2,3, \ldots m\right\}$

Where $\mu\left(p_{i}, p_{j}\right)$ and $\mu\left(s_{i}, s_{j}\right)$ are the values of the characteristic function of belonging.

$[A]$ and $[B]$ coincide by nature, since both are reflexive; that is, in the diagonal, $\mu\left(p_{i}, p_{i}\right)=$ 1 and $\mu\left(s_{j}, s_{j}\right)=1$. This means that each element has the highest impact on itself.

On the other hand, matrices $[\mathrm{A}]$ and $[\mathrm{B}]$ do not have to be symmetric. This means that there can be at least one pair of sub-indexes $i, j$ such that $i \neq j$, such that:

$$
\mu\left(p_{i}, p_{j}\right) \neq \mu\left(p_{j}, p_{i}\right) \text { y } \mu\left(s_{i}, s_{j}\right) \neq \mu\left(s_{j}, s_{i}\right)
$$

\footnotetext{
"Visión de Futuro" Año 18, Volumen $N^{\circ} 25$ No 1, Enero - Junio 2021 - Pág 24 - 42

URL de la Revista: http://visiondefuturo.fce.unam.edu.ar/index.php/visiondefuturo/index

URL del Documento: https://visiondefuturo.fce.unam.edu.ar/index.php/visiondefuturo/issue/view/19 
For example, if the creation of jobs affects trust in politicians at a certain level, trust in politicians does not necessarily have an impact on job creation, and if it does, there is no reason for it to produce the same incidence.

As Kaufmann and Gil Aluja (1988) indicate, once the three incidence matrices [D], [A], and $[B]$ are constructed, the mathematical operation that allows us to know the incidence of $[A]$ on $[D]$ and of $[D]$ on $[B]$ is the maximum-minimum or simply the max-min composition. Said composition is expressed as:

$$
[\mathrm{A}] \circ[\mathrm{D}] \circ[\mathrm{B}]=\left[\mathrm{D}^{*}\right]
$$

Taking care of the sizes of the matrices when executing the operations, the new matrix $\left[D^{*}\right]$ gathers the incidences between causes and second-order effects and is called the secondgeneration effects matrix. Figure $\mathrm{N}^{\circ} 2$.

Gil Lafuente and Barcellos (2010) mention that this matrix captures the initial causal relations affected by the possible interpolated incidence of a given cause or effect.

\begin{tabular}{|c|c|c|}
\hline$p_{1}$ & $\mathrm{p}_{2}$ & $p_{n}$ \\
\hline 1 & $\mu\left(p_{1}, p_{2}\right)$ & $\mu\left(p_{1}, p_{n}\right)$ \\
\hline$\mu\left(p_{2}, p_{1}\right)$ & 1 & $\mu\left(p_{2}, p_{n}\right)$ \\
\hline$\mu\left(p_{n}, p_{1}\right)$ & $\mu\left(p_{n}, p_{2}\right)$ & 1 \\
\hline
\end{tabular}

[A]

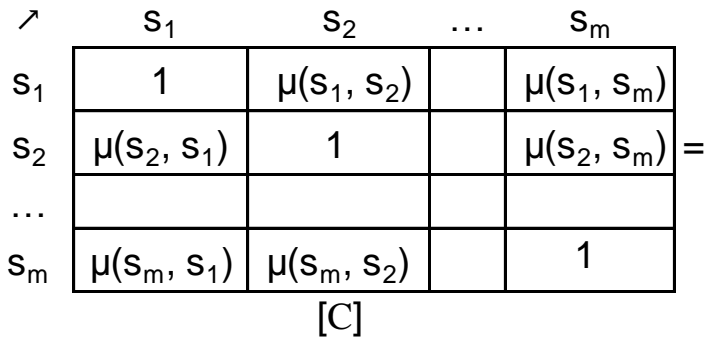

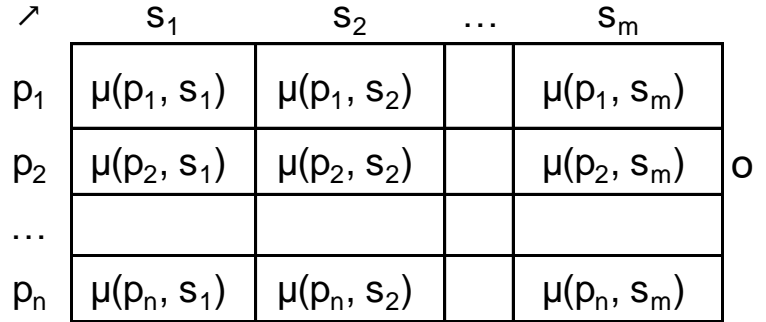

[D]

\begin{tabular}{|c|c|c|}
\hline$s_{1}$ & $\mathrm{~s}_{2}$ & $s_{m}$ \\
\hline$\mu^{*}\left(p_{1}, s_{1}\right)$ & $\mu^{*}\left(p_{1}, s_{2}\right)$ & $\mu^{*}\left(p_{1}, s_{m}\right)$ \\
\hline$\mu^{*}\left(p_{2}, s_{1}\right)$ & $\mu^{*}\left(p_{2}, s_{2}\right)$ & $\mu^{*}\left(p_{2}, s_{m}\right)$ \\
\hline$\mu^{*}\left(p_{n}, s_{1}\right)$ & $\mu^{*}\left(p_{n}, s_{2}\right)$ & $\mu^{*}\left(p_{n}, s_{m}\right)$ \\
\hline
\end{tabular}

Figure $\mathbf{N}^{\circ}$ 2. Second-generation effects matrix [ $\left.\mathrm{D}^{*}\right]$ Source: Prepared by the author

Continuing with this brief presentation of the methodology of the Theory of Forgotten Effects, Kaufmann and Gil Aluja (1988) propose to determine the existence of such effects in order to obtain the mathematical difference, cell by cell, between the second-generation matrix $\left[D^{*}\right]$ and the direct or first-generation incidence matrix [D]. If the differences are zero or very close to zero, this means that there are no Forgotten Effects; however, if the differences move away from the zero value, this will reveal the degree to which certain causal relations have been forgotten or are taken as obvious.

This last matrix $[O]=\left[D^{*}\right]-[D]$ displays the Forgotten Effects. Figure $N^{\circ} 3$.

\footnotetext{
"Visión de Futuro" Año 18, Volumen No 25 N 1, Enero - Junio 2021 - Pág 24 - 42 


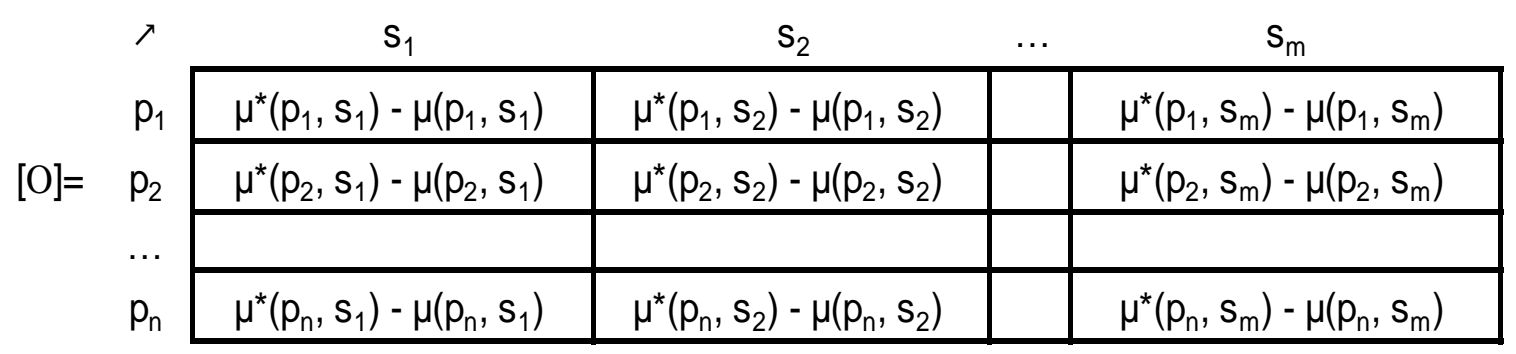

Figure $\mathrm{N}^{\circ}$ 3. Matrix of Forgotten Effects

Source: Prepared by the author

Analyzing this last matrix, we can identify the elements with the highest valuation: the greater the value, the greater the degree of forgetfulness between $p_{i}$ and $s_{j}$ produced in the first-order incidence matrix. Rodríguez, Ramírez, and Díaz (2008) mention that this matrix reveals the effects that individuals or experts do not take into account when evaluating the relationships between the entities under analysis. In several studies conducted with this methodology, it is customary to mention that a value of 0.4 or more provides a good criterion to analyze the Forgotten Effects of that cell. However, this criterion can be flexible, depending on the entities analyzed.

\section{Forgotten Effects between the Public Agenda and Political Attitudes in Mexico}

With the methodology explained in the section above, we will now illustrate the existence of Forgotten Effects in concerns that are common among citizens and how these issues affect the attitudes experienced by individuals regarding certain components of the political system on the west side of the Mexico City Metropolitan Area.

As a point of reference, we started by using the public agenda in Mexico of a 2011-2012 pre-electoral study prepared by Corral (2016). This research included the design of the public agenda through opinion studies prepared by the market research firm Mercaei and published by the Presidency of the Republic on its website (the current government eliminated the link to this website). These surveys were carried out considering a 95\% confidence level with a maximum error of $3 \%$.

For our study, we attempted to find the same information coinciding with the 2017-2018 pre-election period. However, Mercaei did not conduct another study of this type, and although we requested an update from the Presidency of the Republic through its official website, we did not receive a response to our request.

Therefore, we decided to adopt most of the main topics on the public agenda used by Corral (2016), assuming that in a span of time as brief as that between 2012 and 2018, the number of differences would be limited.

\footnotetext{
"Visión de Futuro" Año 18, Volumen No 25 N 1, Enero - Junio 2021 - Pág 24 - 42

URL de la Revista: http://visiondefuturo.fce.unam.edu.ar/index.php/visiondefuturo/index

URL del Documento: https://visiondefuturo.fce.unam.edu.ar/index.php/visiondefuturo/issue/view/19

ISSN 1668 - 8708 - Versión en Línea

E-mail: revistacientifica@fce.unam.edu.ar
} 
McCombs and Evatt (1995) affirm that an agenda cannot be considered merely a list of important subjects, but should be considered a way to put matters of importance in order. Therefore, in our case, we respected the order of the topics selected from the agenda mentioned above, except for the topic of education that was added at the end of the list, considering the importance of this issue based on the 2012 Panel Study of the National Survey on Political Culture and Citizen Practices (ENCUP) (http://www.encup.gob.mx/). It should be noted that the agenda used is not exhaustive and could also be different depending on the country and the point in time.

Table $N^{\circ} 1$ includes the list of the 12 topics on the public agenda that act as causes in the model.

$$
\begin{gathered}
P=\left\{p_{1}, p_{2}, p_{3}, p_{4}, p_{5}, p_{6}, p_{7}, p_{8}, p_{9}, p_{10}, p_{11}, p_{12}\right\} \\
\text { Table } \mathbf{N}^{\circ} \text { 1. Topics on the Public Agenda }
\end{gathered}
$$

\begin{tabular}{|c|l|c|l|}
\hline$p_{1}$ & Insecurity & $p_{7}$ & Corruption \\
\hline$p_{2}$ & Unemployment & $p_{8}$ & Inner Life of Political Parties \\
\hline$p_{3}$ & The Economy & $p_{9}$ & Natural Disaster or Catastrophe \\
\hline$p_{4}$ & $\begin{array}{l}\text { Drug Trafficking and Organized } \\
\text { Crime }\end{array}$ & $p_{10}$ & Election of Candidates for Public Office \\
\hline$p_{5}$ & Poverty & $p_{11}$ & Reforms, Laws, and Decrees \\
\hline$p_{6}$ & Government Efficiency & $p_{12}$ & Education \\
\hline
\end{tabular}

Source: Prepared by the author, from Corral (2016)

Regarding political attitudes, we identified five that include the three dimensions or orientations of political culture indicated by García Luengo as cited by Aruguete and Muñiz (2012), these are the affective, cognitive, and behavioral dimensions.

Table $N^{\circ} 2$ presents the list of political attitudes included in the model as effects on topics on the public agenda.

$$
\mathrm{S}=\left\{\mathrm{S}_{1}, \mathrm{~s}_{2}, \mathrm{~S}_{3}, \mathrm{~S}_{4}, \mathrm{~S}_{5}\right\}
$$

Table $\mathbf{N}^{\circ} 2$ List of Political Attitudes

\begin{tabular}{|c|c|l|}
\hline Affective Dimension & $\mathrm{S}_{1}$ & Trust in Government Leaders in General \\
\cline { 2 - 3 } & $\mathrm{S}_{2}$ & Trust in Political Parties \\
\cline { 2 - 3 } Cognitive Dimension & $\mathrm{S}_{3}$ & $\begin{array}{l}\text { Trust in Institutions (legislative bodies and } \\
\text { Institutions, such as the National Electoral Institute } \\
\text { (INE) and the Electoral Court. }\end{array}$ \\
\cline { 2 - 3 } Behavioral Dimension & $\mathrm{S}_{4}$ & $\begin{array}{l}\text { Interest in Politics (curiosity to learn about issues } \\
\text { related to politics) }\end{array}$ \\
\cline { 2 - 3 } & $\mathrm{S}_{5}$ & $\begin{array}{l}\text { Intention to Participate in Politics (by voting or other } \\
\text { unconventional means such as demonstrations or } \\
\text { popular movements) }\end{array}$ \\
\hline
\end{tabular}

Source: Prepared by the author, from Aruguete and Muñiz (2012)

Once the $\mathrm{P}$ elements were defined as causes and the $\mathrm{S}$ elements as effects, we conducted 120 personal interviews with citizens living on the west side of the Mexico City Metropolitan Area. The age limit was set between 40 and 80, since citizens aged 40 and older have experienced a good part of contemporary Mexican politics, considering the

\footnotetext{
"Visión de Futuro" Año 18, Volumen No 25 N 1, Enero - Junio 2021 - Pág 24 - 42

URL de la Revista: http://visiondefuturo.fce.unam.edu.ar/index.php/visiondefuturo/index

URL del Documento: https://visiondefuturo.fce.unam.edu.ar/index.php/visiondefuturo/issue/view/19

ISSN 1668 - 8708 - Versión en Línea

E-mail: revistacientifica@fce.unam.edu.ar
} 
materialization of a more open struggle between political parties since the end of the last century, which has given rise to party alternation. The sample was constituted by an equal distribution of $50 \%$ male and $50 \%$ female those interviewed with a high school education or above.

Before starting the interview, we clarified the meaning of the term incidence as a subjective assessment of cause and effect among the elements to be assessed.

The valuation of each cell between causes and effects was carried out with the following 11-point endecadary scale.

0: null incidence

0.1 : practically null incidence

0.2: almost null incidence

0.3: very weak incidence

0.4 : weak incidence

0.5: medium incidence

0.6: sensitive incidence

0.7 : considerable incidence

0.8: strong incidence

0.9 : very strong incidence

1: major incidence

Before starting to apply the Forgotten Effects methodology, the valuations made by all citizens interviewed on the subject matter of this paper must be aggregated.

To achieve this aggregation, in the field of uncertainty, Kaufmann and Gil Aluja (1993), define expertage as the process involved in applying a survey to a specific group of experts (the 120 citizens interviewed in this case), using a relatively simple process to obtain a value representing the aggregate opinion of the citizens surveyed for each incidence in our model.

Table $\mathrm{N}^{\circ} 3$ illustrates, by way of example, how we obtained the aggregate opinion of the incidence between the topic of Insecurity with the Intention to Participate in Politics $\left(p_{1} \rightarrow s_{5}\right)$

Step 1. Statistics or absolute frequency. The number of times that the same incidence valuation is obtained from the citizens is counted using values from 0 to 1 (endecadary valuation).

Step 2. Relative or normalized frequency. The absolute frequency table is used to divide each value by the total number of citizens-120, in this case.

Step 3. Accumulation of complementary frequencies. The relative frequencies are accumulated starting the aggregation from the bottom up; that is, from 1 to 0 , thus obtaining a tool for appraisal by a group of experts, the experton.

\footnotetext{
"Visión de Futuro" Año 18, Volumen $N^{0} 25$ No 1, Enero - Junio 2021 - Pág 24 - 42 
Gil Aluja (2002), notes that an experton thus represented is the uncertain number that constitutes the aggregation of quantifiable opinions in numerical figures, keeping all the information and allowing for any subsequent linear or non-linear operation. When working with means, in this case, we lose information before it becomes necessary.

Step 4. The frequency accumulation column is then added without considering 1 in the degree of assumption equal to zero. The sum is 4.883 .

Step 5. Finally, the value obtained from the previous sum is divided by 10 , which is the number of levels comprising the degree of assumption ranging from 0.1 to 1 . In this case it is: $4.883 / 10=0.4883=0.5$ with one decimal.

The value of 0.5 represents the aggregate opinion of the 120 citizens with respect to the incidence of Insecurity in relation to the Intention to Participate in Politics. See Table $N^{\circ} 3$.

Table $N^{\circ} 3$ Expertage: Insecurity and the Intention to Participate in Politics

\begin{tabular}{|c|c|c|c|}
\hline $\begin{array}{c}\left.\text { ( } \mathrm{p}_{1}, \mathrm{~S} 5\right) \\
\text { Degree of } \\
\text { Assumption }\end{array}$ & Absolute Frequency & Relative Frequency & $\begin{array}{c}\text { Accumulation of } \\
\text { Frequencies }\end{array}$ \\
\hline 0 & 19 & 0.158 & 1.000 \\
\hline 0.1 & 5 & 0.042 & 0.842 \\
\hline 0.2 & 5 & 0.042 & 0.800 \\
\hline 0.3 & 11 & 0.092 & 0.758 \\
\hline 0.4 & 10 & 0.083 & 0.667 \\
\hline 0.5 & 19 & 0.158 & 0.583 \\
\hline 0.6 & 9 & 0.075 & 0.425 \\
\hline 0.7 & 12 & 0.100 & 0.350 \\
\hline 0.8 & 14 & 0.117 & 0.250 \\
\hline 0.9 & 7 & 0.058 & 0.133 \\
\hline 1 & 9 & 0.075 & 0.075 \\
\hline Total & 120 & 1.000 & 4.883 \\
\hline & & Aggregate Opinion & 0.5 \\
\hline
\end{tabular}

Source: Prepared by the author

This procedure is used to form each cell in the aggregate matrix [D] of direct incidences with the information provided by the 120 citizens, and the figures in these cells are the levels of direct or first-order incidences. Matrix $\mathrm{N}^{\circ} 1$.

\footnotetext{
"Visión de Futuro" Año 18, Volumen No 25 No 1, Enero - Junio 2021 - Pág 24 - 42 
Matrix № 1. Aggregate Direct incidence Matrix [D]

\begin{tabular}{|c|c|c|c|c|c|}
\hline $\begin{array}{l}\text { [D] effects } \\
\text { causes } \nearrow\end{array}$ & $\begin{array}{l}\text { Trust in } \\
\text { Goverment } \\
\text { Leaders in } \\
\text { General }\end{array}$ & $\begin{array}{c}\text { Trust in Political } \\
\text { Parties }\end{array}$ & $\begin{array}{c}\text { Trust in } \\
\text { institutions }\end{array}$ & Interest in Politics & $\begin{array}{l}\text { Intention to } \\
\text { Participate in } \\
\text { Politics }\end{array}$ \\
\hline Insegurity & 0,7 & 0,5 & 0,5 & 0,7 & 0,5 \\
\hline Unemployment & 0,7 & 0,5 & 0,5 & 0,7 & 0,5 \\
\hline The Economy & 0,7 & 0,5 & 0,5 & 0,7 & 0,8 \\
\hline $\begin{array}{c}\text { Drug Trafficking and } \\
\text { Organized Crime }\end{array}$ & 0,7 & 0,7 & 0,5 & 0,7 & 0,5 \\
\hline Poverty & 0,7 & 0,5 & 0,5 & 0,7 & 0,7 \\
\hline $\begin{array}{l}\text { Government } \\
\text { Efficiency }\end{array}$ & 0,7 & 0,7 & 0,7 & 0,7 & 0,7 \\
\hline Corruption & 0,7 & 0,8 & 0,7 & 0,8 & 0,7 \\
\hline $\begin{array}{c}\text { Inner Life of Political } \\
\text { Parties }\end{array}$ & 0,5 & 0,7 & 0,7 & 0,7 & 0,5 \\
\hline $\begin{array}{l}\text { Natural Disaster or } \\
\text { Catastrophe }\end{array}$ & 0,3 & 0,3 & 0,3 & 0,5 & 0,5 \\
\hline $\begin{array}{c}\text { Election of } \\
\text { Candidates for Public } \\
\text { Office }\end{array}$ & 0,7 & 0,7 & 0,7 & 0,7 & 0,7 \\
\hline $\begin{array}{c}\text { Reforms, Laws, and } \\
\text { Decrees }\end{array}$ & 0,7 & 0,7 & 0,7 & 0,7 & 0,7 \\
\hline Education & 0,7 & 0,7 & 0,7 & 0,7 & 0,8 \\
\hline
\end{tabular}

Source: Prepared by the author, based on interviews and using expertage

Our objective in this research is to apply the Theory of Forgotten Effects to identify the existence of relationships that are frequently omitted by not taking into account the effects created by both the causes and effects themselves.

In this case, the citizens interviewed established the incidences between the causes as themselves and the effects themselves. These aggregate matrices are Matrix $\mathrm{N}^{\circ} 2$ and Matrix $N^{\circ} 3$, respectively, as follows.

\footnotetext{
"Visión de Futuro" Año 18, Volumen $N^{0} 25$ No 1, Enero - Junio 2021 - Pág 24 - 42

URL de la Revista: http://visiondefuturo.fce.unam.edu.ar/index.php/visiondefuturo/index

URL del Documento: https://visiondefuturo.fce.unam.edu.ar/index.php/visiondefuturo/issue/view/19

ISSN 1668 - 8708 - Versión en Línea

E-mail: revistacientifica@fce.unam.edu.ar
} 
Matrix $\mathbf{N}^{\circ}$ 2. Aggregate incidence Matrix $[\mathrm{A}]$ among Topics on the Public Agenda

\begin{tabular}{|c|c|c|c|c|c|c|c|c|c|c|c|c|}
\hline $\begin{array}{l}{[\mathrm{A}] \text { causes }} \\
\text { causes }>\end{array}$ & Insegurity & $\begin{array}{c}\text { Unemploym } \\
\text { ent }\end{array}$ & $\begin{array}{c}\text { The } \\
\text { Economy }\end{array}$ & $\begin{array}{l}\text { Drug } \\
\text { Trafficking } \\
\text { and } \\
\text { Organized } \\
\text { Crime }\end{array}$ & Poverty & $\begin{array}{l}\text { Government } \\
\text { Efficiency }\end{array}$ & Corruption & $\begin{array}{c}\text { Inner Life of } \\
\text { Political } \\
\text { Parties }\end{array}$ & $\begin{array}{c}\text { Natural } \\
\text { Disaster or } \\
\text { Catastrophe }\end{array}$ & \begin{tabular}{|c|} 
Election of \\
Candidates for \\
Public Office \\
\end{tabular} & $\begin{array}{l}\text { Reforms, } \\
\text { Laws, and } \\
\text { Decrees }\end{array}$ & Education \\
\hline Insegurity & 1 & 0,8 & 0,8 & 0,9 & 0,7 & 0,7 & 0,9 & 0,5 & 0,2 & 0,7 & 0,5 & 0,7 \\
\hline Unemployment & 0,8 & 1 & 0,9 & 0,9 & 0,9 & 0,7 & 0,8 & 0,3 & 0,2 & 0,5 & 0,7 & 0,7 \\
\hline The Economy & 0,8 & 0,9 & 1 & 0,9 & 0,8 & 0,7 & 0,8 & 0,7 & 0,3 & 0,7 & 0,7 & 0,8 \\
\hline $\begin{array}{c}\text { Drug Trafficking } \\
\text { and Organized } \\
\text { Crime }\end{array}$ & 1 & 0,8 & 0,8 & 1 & 0,8 & 0,7 & 0,9 & 0,7 & 0,1 & 0,8 & 0,7 & 0,7 \\
\hline Poverty & 0,8 & 0,9 & 0,9 & 0,9 & 1 & 0,5 & 0,8 & 0,5 & 0,3 & 0,7 & 0,5 & 0,8 \\
\hline $\begin{array}{l}\text { Government } \\
\text { Efficiency }\end{array}$ & 0,8 & 0,7 & 0,9 & 0,8 & 0,8 & 1 & 0,8 & 0,7 & 0,2 & 0,8 & 0,8 & 0,8 \\
\hline Corruption & 0,9 & 0,8 & 0,8 & 0,9 & 0,8 & 0,8 & 1 & 0,8 & 0,2 & 0,9 & 0,8 & 0,7 \\
\hline $\begin{array}{c}\text { Inner Life of } \\
\text { Political Parties }\end{array}$ & 0,3 & 0,5 & 0,5 & 0,7 & 0,7 & 0,8 & 0,8 & 1 & 0,2 & 0,8 & 0,7 & 0,5 \\
\hline $\begin{array}{c}\text { Natural Disaster or } \\
\text { Catastrophe }\end{array}$ & 0,3 & 0,5 & 0,7 & 0,2 & 0,5 & 0,3 & 0,5 & 0,2 & 1 & 0,2 & 0,3 & 0,2 \\
\hline $\begin{array}{l}\text { Election of } \\
\text { Candidates for } \\
\text { Public Office }\end{array}$ & 0,5 & 0,5 & 0,7 & 0,7 & 0,7 & 0,8 & 0,8 & 0,8 & 0,2 & 1 & 0,5 & 0,5 \\
\hline $\begin{array}{c}\text { Reforms, Laws, } \\
\text { and Decrees }\end{array}$ & 0,7 & 0,7 & 0,8 & 0,7 & 0,7 & 0,8 & 0,7 & 0,7 & 0,3 & 0,7 & 1 & 0,8 \\
\hline Education & 0,7 & 0,8 & 0,8 & 0,8 & 0,8 & 0,7 & 0,8 & 0,7 & 0,3 & 0,7 & 0,7 & 1 \\
\hline
\end{tabular}

Source: Prepared by the author, based on interviews and using expertage

Matrix $\mathbf{N}^{\circ}$ 3. Aggregate Matrix $[\mathrm{B}]$ of incidences among Attitudes

\begin{tabular}{|c|c|c|c|c|c|}
\hline $\begin{array}{c}\text { [ B] effects } \\
\text { effects }>\end{array}$ & $\begin{array}{c}\text { Trust in Goverment } \\
\text { Leaders in General }\end{array}$ & $\begin{array}{c}\text { Trust in Political } \\
\text { Parties }\end{array}$ & Trust in institutions & $\begin{array}{c}\text { Interest in } \\
\text { Politics }\end{array}$ & $\begin{array}{c}\text { Intention to } \\
\text { Participate in } \\
\text { Politics }\end{array}$ \\
\hline $\begin{array}{c}\text { Trust in } \\
\text { Goverment } \\
\text { Leaders in } \\
\text { General }\end{array}$ & 1 & 0,8 & 0,7 & 0,7 & 0,7 \\
\hline $\begin{array}{c}\text { Trust in Political } \\
\text { Parties }\end{array}$ & 0,7 & 1 & 0,7 & 0,7 & 0,7 \\
\hline $\begin{array}{c}\text { Trust in } \\
\text { institutions }\end{array}$ & 0,7 & 0,7 & 1 & 0,7 & 0,7 \\
\hline $\begin{array}{c}\text { Interest in Politics } \\
\text { Intention to }\end{array}$ & 0,5 & 0,5 & 0,5 & 1 & 0,8 \\
\hline $\begin{array}{c}\text { Participate in } \\
\text { Politics }\end{array}$ & 0,5 & 0,3 & & & \\
\hline
\end{tabular}

Source: Prepared by the author, based on interviews and using expertage

\footnotetext{
"Visión de Futuro" Año 18, Volumen $N^{0} 25$ No 1, Enero - Junio 2021 - Pág 24 - 42

URL de la Revista: http://visiondefuturo.fce.unam.edu.ar/index.php/visiondefuturo/index

URL del Documento: https://visiondefuturo.fce.unam.edu.ar/index.php/visiondefuturo/issue/view/19

ISSN 1668 - 8708 - Versión en Línea

E-mail: revistacientifica@fce.unam.edu.ar
} 
Having obtained the $[\mathrm{D}],[\mathrm{A}]$, and $[\mathrm{B}]$ matrices, as noted by Kaufmann and Gil Aluja (1988), the mathematical operation that allows us to determine the incidence that $[\mathrm{A}]$ produces on [D] and [D] on [B], is the maximum-minimum or max-min composition and is expressed as follows:

$$
[\mathrm{A}] \circ[\mathrm{D}] \circ[\mathrm{B}]=\left[\mathrm{D}^{*}\right]
$$

The program used to perform the operations between the matrices mentioned above was specifically developed to work on models based on the mathematics of uncertainty to recover the Forgotten Effects in incidence relationships. ${ }^{1}$

Kaufmann and Gil Aluja (1988) call $\left[\mathrm{D}^{*}\right]$ the matrix of second-order incidences, and it expresses the effects of $[A]$ and $[B]$ in conjunction. Matrix $N^{\circ} 4$.

\section{Matrix $N^{\circ}$ 4. Second-Order incidence Matrix $\left[D^{\star}\right]$}

\begin{tabular}{|c|c|c|c|c|c|}
\hline $\begin{array}{c}{\left[\mathrm{D}^{\star}\right]=[\mathrm{A}] \circ[\mathrm{D}] \circ[\mathrm{B}]} \\
\text { causes } \rightarrow \text { efects }\end{array}$ & $\begin{array}{l}\text { Trust in } \\
\text { Goverment } \\
\text { Leaders in } \\
\text { General }\end{array}$ & $\begin{array}{c}\text { Trust in Political } \\
\text { Parties }\end{array}$ & Trust in institutions & $\begin{array}{l}\text { Interest in } \\
\text { Politics }\end{array}$ & $\begin{array}{c}\text { Intention to } \\
\text { Participate in } \\
\text { Politics }\end{array}$ \\
\hline Insegurity & 0,7 & 0,8 & 0,7 & 0,8 & 0,8 \\
\hline Unemployment & 0,7 & 0,8 & 0,7 & 0,8 & 0,8 \\
\hline The Economy & 0,7 & 0,8 & 0,7 & 0,8 & 0,8 \\
\hline $\begin{array}{l}\text { Drug Trafficking and } \\
\text { Organized Crime }\end{array}$ & 0,7 & 0,8 & 0,7 & 0,8 & 0,8 \\
\hline Poverty & 0,7 & 0,8 & 0,7 & 0,8 & 0,8 \\
\hline Government Efficiency & 0,7 & 0,8 & 0,7 & 0,8 & 0,8 \\
\hline Corruption & 0,7 & 0,8 & 0,7 & 0,8 & 0,8 \\
\hline $\begin{array}{c}\text { Inner Life of Political } \\
\text { Parties }\end{array}$ & 0,7 & 0,8 & 0,7 & 0,8 & 0,8 \\
\hline $\begin{array}{c}\text { Natural Disaster or } \\
\text { Catastrophe }\end{array}$ & 0,7 & 0,7 & 0,7 & 0,7 & 0,7 \\
\hline $\begin{array}{l}\text { Election of Candidates } \\
\text { for Public Office }\end{array}$ & 0,7 & 0,8 & 0,7 & 0,8 & 0,8 \\
\hline $\begin{array}{c}\text { Reforms, Laws, and } \\
\text { Decrees }\end{array}$ & 0,7 & 0,7 & 0,7 & 0,8 & 0,8 \\
\hline Education & 0,7 & 0,8 & 0,7 & 0,8 & 0,8 \\
\hline
\end{tabular}

Source: Prepared by the author using FuzzyLog

In the presentation of this methodology, it was noted that Gil Lafuente and Barcellos (2010) indicate that matrix $\left[\mathrm{D}^{\star}\right]$ captures the initial causal relationships affected by the possible interpolated incidence of a cause or effect. Therefore, according to the Theory of Forgotten Effects developed by Kaufmann and Gil Aluja (1988), if we obtain the matrix difference cell by

\footnotetext{
${ }^{1}$ The Rights of Use correspond to Professor Anna María Gil Lafuente, researcher at the University of Barcelona. http://www.fuzzyeconomics.com/fuzzylog

"Visión de Futuro" Año 18, Volumen No 25 No 1, Enero - Junio 2021 - Pág 24 - 42

URL de la Revista: http://visiondefuturo.fce.unam.edu.ar/index.php/visiondefuturo/index

URL del Documento: https://visiondefuturo.fce.unam.edu.ar/index.php/visiondefuturo/issue/view/19

ISSN 1668 - 8708 - Versión en Línea

E-mail: revistacientifica@fce.unam.edu.ar
} 
cell, between the second-order incidence matrix [ $\left.\mathrm{D}^{\star}\right]$ and the direct incidence matrix [D], we will obtain the Matrix of Forgotten Effects: $[O]=\left[D^{*}\right]-[D]$ Matrix $N^{\circ} 5$.

Matrix $N^{\circ}$. Matrix of Forgotten Effects [O]

\begin{tabular}{|c|c|c|c|c|c|}
\hline $\begin{array}{c}{[\mathrm{O}]=\left[\mathrm{D}^{*}-\mathrm{D}\right]} \\
\text { causes } \rightarrow \text { effects }\end{array}$ & $\begin{array}{l}\text { Trust in Goverment } \\
\text { Leaders in General }\end{array}$ & $\begin{array}{c}\text { Trust in Political } \\
\text { Parties }\end{array}$ & Trust in institutions & $\begin{array}{l}\text { Interest in } \\
\text { Politics }\end{array}$ & $\begin{array}{l}\text { Intention to } \\
\text { Participate in } \\
\text { Politics }\end{array}$ \\
\hline Insegurity & 0 & 0,3 & 0,2 & 0,1 & 0,3 \\
\hline Unemployment & 0 & 0,3 & 0,2 & 0,1 & 0,3 \\
\hline The Economy & 0 & 0,3 & 0,2 & 0,1 & 0 \\
\hline $\begin{array}{l}\text { Drug Trafficking and } \\
\text { Organized Crime }\end{array}$ & 0 & 0,1 & 0,2 & 0,1 & 0,3 \\
\hline Poverty & 0 & 0,3 & 0,2 & 0,1 & 0,1 \\
\hline Government Efficiency & 0 & 0,1 & 0 & 0,1 & 0,1 \\
\hline Corruption & 0 & 0 & 0 & 0 & 0,1 \\
\hline $\begin{array}{c}\text { Inner Life of Political } \\
\text { Parties }\end{array}$ & 0,2 & 0,1 & 0 & 0,1 & 0,3 \\
\hline $\begin{array}{l}\text { Natural Disaster or } \\
\text { Catastrophe }\end{array}$ & 0,4 & 0,4 & 0,4 & 0,2 & 0,2 \\
\hline $\begin{array}{l}\text { Election of Candidates } \\
\text { for Public Office }\end{array}$ & 0 & 0,1 & 0 & 0,1 & 0,1 \\
\hline $\begin{array}{c}\text { Reforms, Laws, and } \\
\text { Decrees }\end{array}$ & 0 & 0 & 0 & 0,1 & 0,1 \\
\hline Education & 0 & 0,1 & 0 & 0,1 & 0 \\
\hline
\end{tabular}

Source: Prepared by the author using FuzzyLog

\section{Results}

One of the first general reflections on the Matrix of Forgotten Effects (Matrix $N^{\circ} 5$ ), is that the values of the cells that are very close to zero or even zero are interpreted as levels where there are no Forgotten Effects between the topics on the public agenda and the political attitudes of citizens. Conversely, if the numerical value moves away from zero, this indicates a Forgotten Effect between a given cause or effect. In the case at hand, we have determined that values equal to or greater than 0.3 are the hidden incidence relationships. That is, the 11 cells in gray show the Forgotten Effects of a cause on an effect.

To demonstrate how this tool functions, below, we present two forgotten effects of the 11 effects identified, which we consider are representative of the current situation in Mexico. The first of these is shown in Table $N^{\circ} 4$ with its Figure $N^{\circ} 4$.

\footnotetext{
"Visión de Futuro" Año 18, Volumen N$^{0} 25$ N 1, Enero - Junio 2021 - Pág 24 - 42

URL de la Revista: http://visiondefuturo.fce.unam.edu.ar/index.php/visiondefuturo/index

URL del Documento: https://visiondefuturo.fce.unam.edu.ar/index.php/visiondefuturo/issue/view/19

ISSN 1668 - 8708 - Versión en Línea

E-mail: revistacientifica@fce.unam.edu.ar
} 
Table N ${ }^{\circ} 4$ First Forgotten Effect: Poverty $\rightarrow$ Trust in Political Parties

\begin{tabular}{|c|c|}
\hline Initial value estimated $[\mathrm{D}]$ & 0.5 \\
\hline Cumulative cause-effect value $\left[\mathrm{D}^{*}\right]$ & 0.8 \\
\hline Difference between values (Forgotten \\
Effect)
\end{tabular}

Source: Prepared by the author, with data obtained from FuzzyLogic

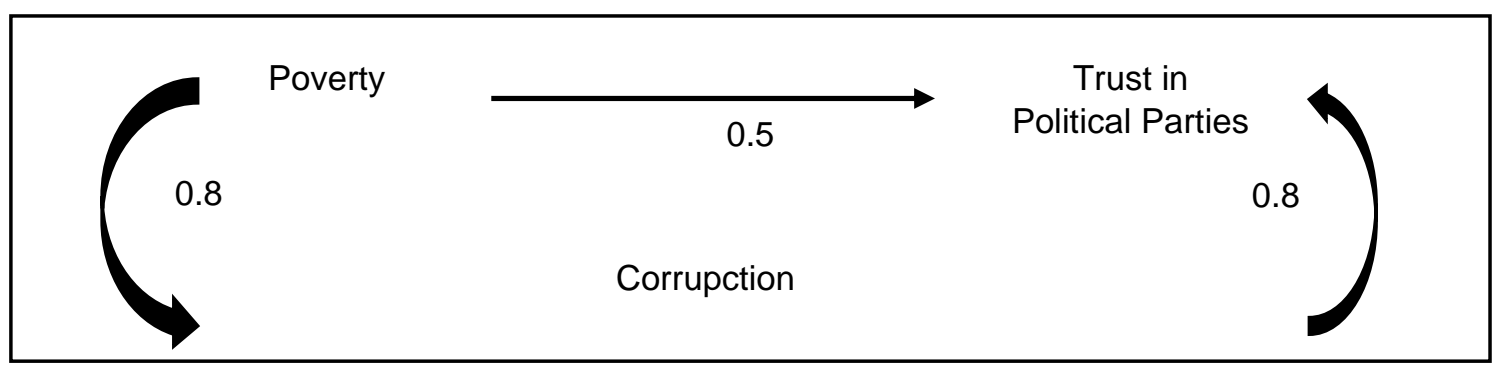

Figure $\mathbf{N}^{\circ}$ 4. Ilustration of the first Forgotten Effect

Source: Prepared by the autor, with data obtained from FuzzyLogic

Although initially, in matrix [D], the incidence between Poverty and Trust in Political Parties was valued at 0.5 , when preparing the second-order matrix $\left[\mathrm{D}^{*}\right]$, the cumulative incidence between these elements increased to 0.8 since there is an intervening element (Corruption) that belongs to the topics on the public agenda and that can magnify and accumulate effects in the initial relationship that those interviewed did not take into account, because of the forgetfulness in this complex relation of incidences between the topics on the public agenda and citizens' political attitudes.

It should be clarified that the value of 0.8 mentioned above is determined by taking the incidence values, through the path of the wide arrows, to select the minimum $(\wedge)$ between them: $(0.8 \wedge 0.8=0.8)$. This demonstrates an opportunity for politicians since they must undeniably fight corruption if they want to increase confidence in political parties, as this produces a strong incidence on Trust in Political Parties.

In fact, one of the main arguments presented by the current president of Mexico, Andrés Manuel López Obrador, that helped him obtain a resounding victory in the July 2018 election, was that his government would eliminate corruption for the first time in the nation's history.

The second Forgotten Effect is presented in Table $\mathrm{N}^{\circ} 5$ with its Figure $\mathrm{N}^{\circ} 5$.

\footnotetext{
“Visión de Futuro" Año 18, Volumen No 25 No 1, Enero - Junio 2021 - Pág 24 - 42 
Table $N^{\circ}$ 5. Second Forgotten Effect: Natural Disaster or Catastrophe $\rightarrow$ Trust in Political

\begin{tabular}{|c|c|}
\hline \multicolumn{2}{|c|}{ Parties } \\
\hline Initial value estimated [D] & 0.3 \\
\hline Cumulative cause-effect value [D*] & 0.7 \\
\hline $\begin{array}{c}\text { Difference between values (Forgotten } \\
\text { Effect) }\end{array}$ & 0.4 \\
\hline Interpolated relevant key relationship: & $\begin{array}{c}\text { The Economy and Trust in Government } \\
\text { Leaders in General }\end{array}$ \\
\hline
\end{tabular}

Source: Prepared by the author, with data obtained from FuzzyLogic

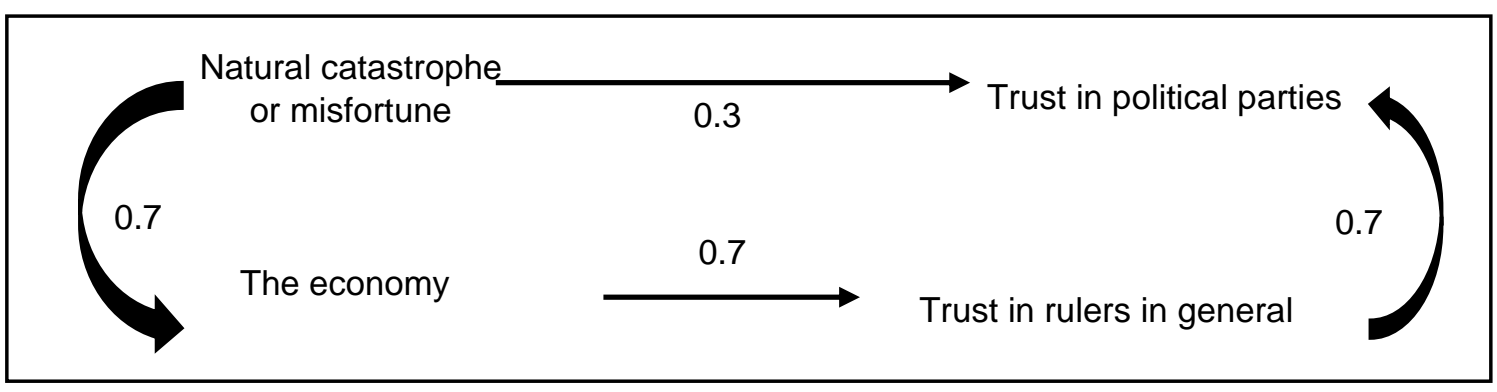

Figure $\mathbf{N}^{\circ} 5$ llustration of the second Forgotten Effect

Source: Prepared by the autor, with data obtained from FuzzyLogic

In this case, the relation of incidence in matrix [D], is 0.3 between Natural Disaster or Catastrophe and Trust in Political Parties. When preparing the second-order matrix $\left[D^{*}\right]$, the cumulative incidence between these elements increases to 0.7. As mentioned above, the values of the path are taken with wide arrows to select the minimum $(\wedge)$ between them: $(0.7 \wedge 0.7 \wedge 0.7=0.7)$. Therefore, there are two intervening elements in this case (The Economy and Trust in Government Leaders in General) that can magnify and accumulate a greater incidence in the initial relationship that was not taken into account by those interviewed, because of the forgetfulness in this complex relationship of incidences between the topics on the public agenda and the people's political attitudes.

The foregoing shows that when a Natural Disaster or Catastrophe occurs, this event affects the Economy and Trust in Government Leaders in General, which provides an opportunity to strengthen Trust in Political Parties.

\section{CONCLUSION}

The current political situation in Mexico has seen better days: the loss of prestige of politicians, political parties, and government institutions, in general, are not minor issues. Inspired by this, this paper aims to identify elements of opportunity to improve the position of the country's political image.

There is a line of research on political issues that addresses the impact or effects on the political attitude of citizens from the media and information outlets (the media agenda in

\footnotetext{
"Visión de Futuro" Año 18, Volumen No 25 N 1, Enero - Junio 2021 - Pág 24 - 42

URL de la Revista: http://visiondefuturo.fce.unam.edu.ar/index.php/visiondefuturo/index

URL del Documento: https://visiondefuturo.fce.unam.edu.ar/index.php/visiondefuturo/issue/view/19

ISSN 1668 - 8708 - Versión en Línea

E-mail: revistacientifica@fce.unam.edu.ar
} 
general). This study can be part of that family, conscious of the differences that exist in the agendas used and the methodologies applied.

The contribution of this paper to political marketing is to provide a causality model through the meaning of incidence that has a subjective nature. The study was carried out during the 2018 presidential campaign, during which people had a heightened sense of political awareness. However, we identified hidden elements that, once revealed, could allow political actors to focus on areas of opportunity to improve their affective, cognitive, behavioral, or participatory ties to citizens.

The tools used to demonstrate the usefulness of expertage to obtain the aggregate opinion of a group of citizens on the subject matter of this article. In addition, the Theory of Forgotten Effects is presented as an analytical and novel instrument in political marketing, which serves to recover hidden links between entities that act as causes and entities that act as effects, contributing in this way to improve the effectiveness in the performance of politicians with their offer to their target audiences.

Lastly, we believe that this study serves as a basis for future research in the field of incidence matrices and the application of the Forgotten Effects recovery methodology in other areas of political marketing.

\section{REFERENCES}

Please refer to articles in Spanish Bibliography.

\section{BIBLIOGRAPHICAL ABSTRACT}

Please refer to articles Spanish Biographical abstract.

\footnotetext{
"Visión de Futuro" Año 18, Volumen $N^{\circ} 25$ No 1, Enero - Junio 2021 - Pág 24 - 42 